\title{
THE FEASIBILITY OF HOT WATER DISINFESTATION OF SUMMERFRUIT
}

\author{
G.F. M'LAREN ${ }^{1}$, J.A. FRASER ${ }^{1}$ and R.M. M'DONALD ${ }^{2}$ \\ The Horticulture and Food Research Institute of New Zealand \\ ${ }^{1}$ Clyde Research Centre, R.D.1, Alexandra, Central Otago \\ ${ }^{2}$ Ruakura Research Centre, Private Bag 3123, Hamilton
}

\begin{abstract}
A commercial-scale hot water bath was tested for the disinfestation of New Zealand flower thripsThrips obscuratus from export summerfruit. Treatment in water at $50^{\circ} \mathrm{C}$ for 2 minutes removed approximately $98 \%$ of adults from nectarines and $90 \%$ from peaches. All adults and larvae were killed on nectarines in that time, but on peaches, just 1 minute (with a wetting agent) was required to kill all life stages, including eggs. Apricots, peaches and nectarines tolerated $50^{\circ} \mathrm{C}$ for 2 minutes. Pesticide residues were reduced by the hot water. This treatment could replace existing preharvest field insecticide applications for thrips control, as soon as international pressures for insecticide withdrawal requires it.
\end{abstract}

Keywords: disinfestation, hot water, New Zealand flower thrips, summerfruit, stonefruit

\section{INTRODUCTION}

The New Zealand flower thrips, Thrips obscuratus (Crawford), is an endemic quarantine pest of summerfruit. It occurs occasionally on summerfruit crops over the growing season, but is particularly attracted to ripening fruit, causing problems at harvest time. The insecticide, carbaryl, is currently applied up to one day before harvest, but prospects for its continued use in this manner are doubtful, based on World Health Organisation data (D. Lunn pers. comm.). A non-chemical method of control would provide a useful alternative, maintaining market access for New Zealand exports and reducing pesticide use in the field. An extended research programme has sought to minimise both damage to the fruit and delays in the packing shed, while optimising the control of all stages of thrips (McLaren and Fraser 1993; McLaren et al. 1994). Trials in 1993 investigated exposures over the temperature range $38-56^{\circ} \mathrm{C}$ and established that thrips were more heat tolerant than apricots in water at $38-44^{\circ} \mathrm{C}$, but apricots were more tolerant than thrips at $48-50^{\circ} \mathrm{C}$, with apricots tolerating 9 minutes and thrips just 3 minutes in a static bath ( $99 \%$ mortality). Subsequent work, using a purpose-built tumbler bath, established that all stages of New Zealand flower thrips were controlled in water at $50^{\circ} \mathrm{C}$ for 2 minutes, and that this treatment would not damage apricots, peaches or nectarines. However, it was also found in 1996 that the tolerance of rain-affected apricots could be as low as 3 minutes at $50^{\circ} \mathrm{C}$ (McLaren unpublished), which is much lower than had been found in the earlier trials, where rain had not been a factor.

In 1996 and 1997, a prototype hot water bath and drier was used to test the tolerance of summerfruit and New Zealand flower thrips to treatments in the $48-50^{\circ} \mathrm{C}$ range and to test the effect of the treatment on pesticide residues. This paper describes the final stages of the development of a commercial scale hot water treatment system, including a cost-benefit analysis.

\section{Insect mortality}

\section{METHODS}


(a) Thrips

Ripe peaches and nectarines, naturally infested with New Zealand flower thrips, were picked and then treated in 1400 litres water in a prototype commercial-scale bath at $50^{\circ} \mathrm{C}$ for 1 or 2 minutes. Some treatments included a wetting agent $(10 \mathrm{ml} / 100$ litres Citowett). All samples, including the untreated controls, consisted of approximately 130 peaches cv. 'White Lady' or 115 nectarines cv. 'Fantasia', with 3 and 5 replications respectively. Treated fruit were packed immediately after treatment into single layer plix trays and held at $20^{\circ} \mathrm{C}$ until inspection. Untreated controls were held in the laboratory in the nylon bags which had been used for their harvest (20 fruit per bag). All samples were inspected within 18-24 hours, when live and dead adults and larvae were identified under a binocular microscope. Confirmation of egg survival required a second inspection, 3 days later, after new larvae had hatched from eggs under the fruit's skin. Adults and larvae, which had been washed off the fruit, were collected in a bag in the bath. However, the number of larvae killed and collected in the bag was probably underestimated due to destruction of larvae by pressurised water compressing them against the cloth bag. This made it impossible to know the initial number of larvae present in each treatment. Therefore, percentage mortality of larvae was estimated by comparing survival in a treatment with that of the untreated control. The same approach was required when calculating percentage mortality of eggs. Since it was impossible to estimate how many eggs were present under the fruit's skin, the number of emerging larvae was compared with those in the untreated control.

Percentage mortality data were arcsine transformed for analysis but presented as raw means.

(b) Leafrollers

A few of the fruit being tested for thrips disinfestation were also naturally infested with leafrollers. The effect of the treatments on the survival of leafrollers was recorded from the samples of 115-130 fruit per treatment, with 8 replications. Surviving leafroller larvae were recorded and then reared to maturity on artificial diet before identification. Data for peaches and nectarines were combined for analysis.

\section{Fruit quality}

Over two seasons (1996 and 1997), two apricot ('Sundrop', 'Valleygold'), two peach ('Improved Flavourcrest', 'Flamecrest') and two nectarine cultivars ('Fantasia', 'Red Diamond') were treated in water at $50^{\circ} \mathrm{C}$ for 2 minutes, graded and packed in single trays, then stored for 3 weeks at $0^{\circ} \mathrm{C}$ followed by 5 days at $20^{\circ} \mathrm{C}$. Between $300-432$ fruit were tested per treatment, with 3 replications After storage, $40 \%$ of each fruit sample was assessed for firmness and soluble solids (Effegi penetrometer with $8 \mathrm{~mm}$ tip and Atago refractometer); all fruit were assessed for external and internal disorders (visual assessments) and the presence and cause of fungal infections. Percentage rots were analysed after arcsine transformation, although raw means are presented.

Fruit flesh temperatures were monitored in five fruit per treatment after each treatment with a Digi-therm probe.

\section{Residue analysis}

Fruit samples were analysed for pesticide residues by solvent extraction, clean-up by partitioning or size-exclusion chromatography and determination by high resolution gas chromatography with dual electron capture and nitrogen-phosphorus detection (Holland and McGhie 1984; Rhoos et al. 1987).

\section{Insect disinfestation}

\section{RESULTS AND DISCUSSION}

\section{(a) Thrips}

The majority of adults ( $98 \%$ on nectarines, $90 \%$ on peaches) were collected in the bath, rather than on the fruit. The addition of a wetting agent reduced the time required to control all stages of New Zealand flower thrips on peaches to 1 minute at $50^{\circ} \mathrm{C}$, but left a few larval survivors on nectarines. The most effective treatment for nectarines was $50^{\circ} \mathrm{C}$ for 2 minutes, without a wetting agent (Table 1 ).

TABLE 1: Mean thrips per treatment killed and removed from fruit in water at $50^{\circ} \mathrm{C}$ after 1 or 2 minutes, with or without the wetting agent (WA), 
Citowett $10 \mathrm{ml} / 100$ litres.

\begin{tabular}{|c|c|c|c|c|c|c|c|}
\hline \multirow[b]{2}{*}{ Treatment } & \multicolumn{3}{|c|}{ Adults } & \multicolumn{2}{|c|}{ Larvae } & \multicolumn{2}{|c|}{ Eggs } \\
\hline & Alive & $\%$ mort & $\begin{array}{c}\% \\
\text { removal }\end{array}$ & Alive & $\begin{array}{l}\% \text { mort. } \\
\text { cf. control }\end{array}$ & $\begin{array}{l}\text { Eggs to } \\
\text { larvae }\end{array}$ & $\begin{array}{l}\% \text { mort. } \\
\text { cf. control }\end{array}$ \\
\hline
\end{tabular}

\begin{tabular}{|c|c|c|c|c|c|c|c|}
\hline \multicolumn{8}{|c|}{ Nectarines cv. 'Fantasia' } \\
\hline $2 \min$ & $0 \mathrm{a}$ & $100 \mathrm{a}$ & 98.1 & & 100 & 0.4 a & 99.5 \\
\hline $1 \mathrm{~min}+\mathrm{WA}$ & $0 \mathrm{a}$ & $100 \mathrm{a}$ & 99.7 & $0.3 \mathrm{a}$ & 98.3 & $0.57 \mathrm{a}$ & 99.3 \\
\hline $2 \min +\mathrm{WA}$ & $0 \mathrm{a}$ & $100 \mathrm{a}$ & 98.7 & $0.8 \mathrm{a}$ & 95.6 & $0.28 \mathrm{a}$ & 99.7 \\
\hline untreated & $53.6 \mathrm{~b}$ & $29 \mathrm{~b}$ & NT & $34 \mathrm{~b}$ & - & $86.6 \mathrm{~b}$ & - \\
\hline Significance $^{1}$ & $<0.01$ & $<0.01$ & $>0.05$ & $<0.01$ & $>0.05$ & $<0.01$ & $>0.05$ \\
\hline \multicolumn{8}{|c|}{ Peaches cv. 'White Lady' } \\
\hline $2 \mathrm{~min}$ & $2.3 \mathrm{a}$ & $99.2 \mathrm{ab}$ & 89.6 & $2.3 \mathrm{a}$ & 96.9 & $0 \mathrm{a}$ & 100 \\
\hline $1 \mathrm{~min}+\mathrm{WA}$ & $0 \mathrm{a}$ & $100 \mathrm{a}$ & 89.3 & $0 \mathrm{a}$ & 100 & $0 \mathrm{a}$ & 100 \\
\hline $2 \mathrm{~min}+\mathrm{WA}$ & $0 \mathrm{a}$ & $100 \mathrm{a}$ & 91.5 & $0 \mathrm{a}$ & 100 & $0 \mathrm{a}$ & 100 \\
\hline untreated & $386 \mathrm{~b}$ & $49.8 \mathrm{~b}$ & NT & $341 \mathrm{~b}$ & - & $1257 \mathrm{~b}$ & - \\
\hline Significance $^{1}$ & $<0.01$ & $<0.01$ & $>0.05$ & $<0.01$ & $>0.05$ & $<0.01$ & $>0.05$ \\
\hline
\end{tabular}

Significance $^{1}$ : Means followed by the same letter in a column were not significantly different by Newman-Keuls test $(\mathrm{P}<0.05)$.

$\mathrm{NT}=$ not tested

(b) Leafrollers

All the hot water treatments reduced leafroller numbers compared with the untreated (Table 2).

TABLE 2: Mortality of naturally infested leafrollers on peaches and nectarines (SE in parentheses) and percentage lost or killed.

\begin{tabular}{|c|c|c|c|c|c|}
\hline Treatment & $\begin{array}{l}\text { Fruit } \\
\text { sample } \\
\text { size }\end{array}$ & $\begin{array}{l}\text { Number of } \\
\text { damaged } \\
\text { fruit }\end{array}$ & $\begin{array}{c}\text { Live } \\
\text { leafrollers }\end{array}$ & $\begin{array}{c}\text { Mean } \\
\text { number } \\
\text { alive }(\mathrm{SE})\end{array}$ & $\begin{array}{l}\text { Percentage killed } \\
\text { or removed in } \\
\text { water or handling }\end{array}$ \\
\hline $2 \min$ & 720 & 20 & 1 & $0.167(0.17)$ & 95 \\
\hline $1 \mathrm{~min}+\mathrm{WA}$ & 720 & 27 & 1 & $0.167(0.17)$ & 96 \\
\hline $2 \min +\mathrm{WA}$ & 705 & 21 & 0 & 0 & 100 \\
\hline untreated & 965 & 42 & 21 & $2.63(0.99)$ & 50 \\
\hline Significance $^{1}$ & & & & & $<0.05$ \\
\hline
\end{tabular}

Significance ${ }^{1}$ : Means followed by the same letter were not significantly different by Newman-Keuls test $(\mathrm{P}<0.05)$. WA $=10 \mathrm{ml} / 100$ litres Citowett.

Equal numbers (7) of greenheaded leafroller (Planotortix octo) and lightbrown apple moth (Epiphyas postvittana) (7) were reared from the surviving larvae. Earlier trials on the control of these two species on fruit indicated that to achieve $99 \%$ mortality in $50^{\circ} \mathrm{C}$ water, 15 minutes would be required for $E$. postvittana and 7-10 minutes for $P$. octo (Jones and Waddell 1994; McLaren unpubl. data respectively). It is likely that the tumbling action of the fruit in the larger bath is responsible for increased water penetration inside leafroller tunnels, compared with that in a static bath (Jones and Waddell 1994) or in the small tumbler bath (McLaren unpubl. data). The level of mortality and removal of leafroller larvae, which was produced in the commercial prototype (95-100\%), is likely to be seen as a useful contribution to the control of these quarantine pests.

\section{Fruit Quality}

Treated fruit stored as well as untreated fruit, with no detrimental effects on external 
or internal quality (data not presented), but the level and cause of postharvest rots varied with cultivar and treatment. Peaches were particularly susceptible to postharvest rots mostly due to brown rot (Monilinia spp.) and grey mould (Botrytis cinerea). There were no differences between treatments in 3 of the 7 trials (Table 3 ). In the 4 trials where differences were found, hot water alone induced more postharvest rots than the untreated in 1 trial and decreased them in another. However, when the fruit were dried after the bath, fewer rots developed compared with the untreated control in 3 trials out of 4 . Generally, the combination of hot water, followed by drying, produced fruit with a similar, or possibly lower, risk of developing postharvest rots than untreated fruit.

TABLE 3: Percentage postharvest rots in summerfruit (standard error in parentheses) after 3 weeks storage at $0^{\circ} \mathrm{C}$ followed by 5 days at $20^{\circ} \mathrm{C}$ following treatment in water at $50^{\circ} \mathrm{C}$ for 2 minutes.

\begin{tabular}{lccccc}
\hline Cultivar & \multicolumn{5}{c}{ Percentage postharvest rots } \\
& Year & untreated & hot water & $\begin{array}{c}\text { hot water } \\
\text { then dried }\end{array}$ & Probability \\
\hline Valleygold & 1996 & $50.7 \mathrm{~b}$ & $45.7 \mathrm{~b}$ & $15.7 \mathrm{a}$ & $<0.01$ \\
Sundrop & 1996 & 11.7 & 17.0 & 12.7 & $>0.05$ \\
Sundrop & 1997 & $3.6 \mathrm{a}$ & $10.53 \mathrm{~b}$ & $6.79 \mathrm{ab}$ & $<0.01$ \\
Fantasia & 1996 & $15.7 \mathrm{~b}$ & $9.7 \mathrm{a}$ & $8.7 \mathrm{a}$ & $<0.01$ \\
Red Diamond & 1997 & 2.2 & 4.6 & 4.5 & $<0.05$ \\
Improved Flavourcrest & 1996 & $69.0 \mathrm{~b}$ & $52.0 \mathrm{ab}$ & $33.3 \mathrm{a}$ & $<0.01$ \\
Flamecrest & 1997 & 50.3 & 64.2 & 65.8 & $>0.05$ \\
Mean & & 29.0 & 29.1 & 21.1 & $>0.05$ \\
& & $(10.2)$ & $(9.1)$ & $(8.3)$ & \\
\hline
\end{tabular}

Means followed by the same letter were not significantly different by Newman-Keuls test $(\mathrm{P}<0.05)$.

The internal temperature of the fruit was raised by $9^{\circ} \mathrm{C}$ in apricots and $6^{\circ} \mathrm{C}$ in peaches (larger fruit), irrespective of the initial fruit temperature. This temperature gain would

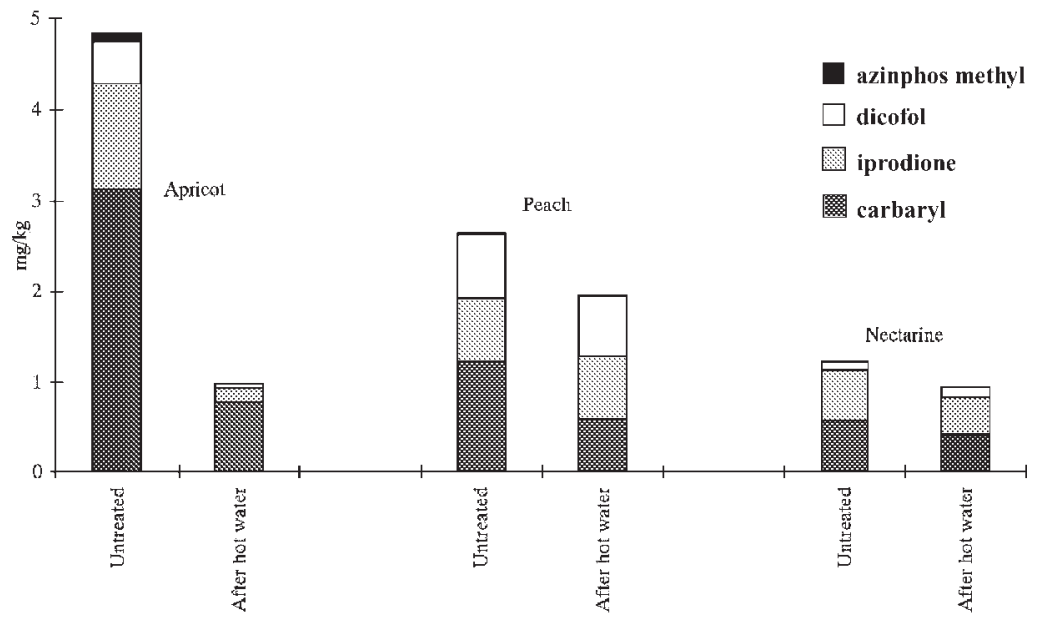

FIGURE 1: Pesticide residues ( $\mathrm{mg} / \mathrm{kg}$ ) from sprays applied in the field on nectarines, peaches and apricots before and after treatment in water at $50^{\circ} \mathrm{C}$ for 2 minutes. 
need to be recovered before transportation.

\section{Pesticide residues}

Hot water treatments reduced the residues of some pesticides on the fruit, particularly carbaryl, but iprodione and dicofol showed little change (except iprodione on apricots) (Fig. 1).

\section{Cost benefit analysis}

\section{(a) Pesticide reduction}

Hot water treatment offers an opportunity for pesticide reduction both in the field and postharvest. Most of the 3-6 field applications of carbaryl, currently applied before harvest and between picks, could be dispensed with. In addition, it is likely that if carbaryl were not being applied at 4 day intervals during harvest, the number of fungicide applications would be reduced and application intervals stretched to 7 days. We estimate, the average export grower would save 3 carbaryl and 2 fungicide applications, and two 'rounds' of the sprayer. This would represent savings of :
carbaryl at 2000 litres/ha:
$\$ 92.40 /$ ha $x 3$ applications
iprodione at 2000 litres/ha:
$\$ 147.40 /$ ha $x 2$ applications
$=\$ 277.20$
application costs of tractor, sprayer and labour @ \$50/ha x 2

$$
=\$ 294.80
$$

TOTAL $=\$ 672.00 /$ ha

\section{(b) Capital Cost Estimates}

The estimated cost of building a hot water bath and drier to fit into an existing packing shed and treat 4 tonnes/hour is approximately $\$ 80,000$ (G. Wansink, E.B McDonald Engineering, Dunedin). Some shed modification, including upgrading of electricity supply systems, may be required to accommodate the equipment (up to \$20,000). A system for disposal of waste water containing pesticide residues at the end of each day (data not presented) would also need to be considered. Planning approval will probably be required from the local authority for waste water disposal. Total cost of building and installing the equipment is, therefore, estimated to be approximately $\$ 100,000$.

(c) Market Access

Currently, there are poor prospects for continued market access for products treated with pesticides close to harvest. Consumers expect to buy 'safe' and therefore pesticidefree products. Carbaryl, in particular, is facing an increasingly uncertain future. A nonchemical treatment that reduces residues and avoids the use of preharvest insecticides would allow New Zealand producers to retain access to international markets without putting the importing country at risk of introducing new horticultural pests. The treatment shows promise for the control of thrips, and to some extent leafrollers; while thrips have consistently been the most common cause of rejection of export fruit, leafrollers are the second (C. Brown, MAF Qual. pers. comm). Therefore, this treatment would be a useful addition to a reduced field programme for the control of both pests, and would thus improve the environment for both orchard staff and beneficial organisms. (d) Cost Benefits

Apart from the installation costs, the packhouse owner would need to evaluate the continuing costs and benefits. In a packing shed handling 3 tonnes/hour, working 6 days/ week for 6 weeks, costs (including depreciation, loss of income (interest) on invested dollars, maintenance, electricity and general running costs $)=6.2 \mathrm{c} / \mathrm{kg}$. Benefits accrued from spray savings $=4.5 \mathrm{c} / \mathrm{kg}$ and maintenance of market access $=70 \mathrm{c} / \mathrm{kg}$. Therefore, operating costs are similar to benefits from saving sprays, so there would be little advantage in installing the equipment unless export markets were at risk. Should this situation arise, however, it would be easy to demonstrate the cost benefits of installing the equipment with a net gain of $68.3 \mathrm{c} / \mathrm{kg}$ fruit treated.

\section{CONCLUSION}

The use of field insecticides close to harvest has become increasingly undesirable and presents special problems for the control of a quarantine pest such as New Zealand flower thrips, which can fly into the crop within hours of harvest, attracted by ripening fruit. Hot water disinfestation, being a non-chemical treatment, is an attractive alternative which is endorsed by the fruit growing community, but the cost of installing it in every export packhouse is an impediment to its adoption. The future of the system appears to depend 
on the prospects for the continued use of carbaryl on export fruit.

\section{ACKNOWLEDGEMENTS}

This work was funded by a Technology for Business Growth grant number SFN501 from the Foundation for Research and Science Technology and Summerfruit New Zealand Incorporated. We thank Evan Blanch, Arlene Bradley and Sue Parker for excellent technical assistance and Colin Malcolm and Alistair Boyd for pesticide residue.

\section{REFERENCES}

Holland, P.T. and McGhie, T.K., 1984. Multi-residue method for determination of pesticides in kiwifruit, apples and berryfruits.J. Assoc. Offic. Anal. 66: 1003-1008.

Jones, V.M. and Waddell, B.C., 1994. Disinfestation of New Zealand summerfruit: mortality response of tydeid mite and lightbrown apple moth following hot water treatment. HortResearch Client Report No. 94/71.

McLaren, G.F. and Fraser, J.A., 1993. Effect of hot water dips on quality of apricots and mortality of New Zealand flower thrips. The Orchardist of New Zealand 66 (11): 49-50.

McLaren, G.F., Fraser, J.A., Rose, K.J. and McDonald, R.M., 1994. Tolerance of New Zealand flower thrips Thrips obscuratus ( Crawford) and three apricot cultivars to hot water.In:Summerfruit Research 1993-94: Executive Summaries. The Orchardist of New Zealand 67 (11): 14-15.

Roos, A.H., Van Munsteren, A.J., Nab, A.J. and Tuinstra, L.G.M. Th., 1987. Universal extraction clean-up procedure for screening of pesticides by extraction with ethyl acetate and size exclusion chromatography. Anal. Chem. Acta 196: 95-100. 